\title{
Morphology of the Eyeball, Orbit and Retina of Atlantic Salmon (Salmo Salar) Alevins under Hypoxic Conditions
}

\author{
Morfología del Bulbo Ocular, Órbita y Retina de Alevines del \\ Salmón del Atlántico (Salmo salar) bajo Condiciones Hipóxicas
}

\author{
Mario Pellón"; Mariana Rojas",;*; Gustavo Saint-Pierre**; Ricardo Hartley ${ }^{* * *}$ \& Mariano del Sol",**,*****
}

PELLÓN, M.; ROJAS, M.; SAINT-PIERRE, G.; HARTLEY, R. \& DEL SOL, M. Morphology of the eyeball, orbit and retina of atlantic salmon (Salmo salar) alevins under hypoxic conditions. Int. J. Morphol., 34(1):320-329, 2016.

SUMMARY: It has been demonstrated that hypoxia retards the growth of fish, reduces the survival of their larvae, deforms their vertebral column, but despite this teleost fish have the ability to completely regenerate many of their tissues, particularly the retina. As we do not have enough information about the effects of hypoxia on the eyeball, orbit and retina of Atlantic salmon (Salmo salar), we propose the following objectives: 1) Compare the morphological changes of the eyeball of fish subject to hypoxia and normoxia. 2) Determine changes in the orbit structure. 3) Describe the retina of salmon alevins. 4). Recognize hypoxic cells using the anti-Hif1 $\alpha$ antibody in the retina of alevins as a sensor. 5) Determine the Shh morphogenic expression in alevins exposed to different times of hypoxia. Around 1,000 Salmo salar alevins were placed in a continuous water flow of $9{ }^{\circ} \mathrm{C}$ at $100 \% \mathrm{SatO}_{2}$ and alevins maintained at a hypoxia of $60 \%$ $\mathrm{SatO}_{2}$. The latter were transferred to normoxia (at days two, four, and eight after hatching). A control group maintained at continuous normoxia and another at continuous hypoxia was also considered. All the alevins were euthanized at 950 UTAs ( \pm 2 months after hatching). Diaphonization (double-stain) according to the Hanken \& Wassersug technique was undertaken to describe the morphology of the periocular cartilage and to measure the ocular diameter. The HIF-1 $\alpha$ factor antibody 1:50, and the anti-Shh antibody dilution of 1:100 were used. The alevins after hatching had large eyeballs with the optic cup having an embryonic shape, even a choroidal fissure. The greatest thickness was observed in the nasal ventral zone which corresponds to a zone of pluripotent cells. The optic cup aspect with embryonic characteristics has only been reported in salmonids. The central retina of the alevins those were cultivated with a $60 \%$ saturation of $\mathrm{O}_{2}$ for two, four or eight days had positive immunostaining when analyzed with the anti-HIF1 $\alpha$ antibody hypoxia sensor. The inner ganglion and nuclear layers had immunopositive cells, with the highest in the alevins that were two days in hypoxia and the lowest when the hypoxia was chronic. Nevertheless, in the latter case the alevins had anatomical deformation of the eyeball and periocular cartilage. The anti-Shh antibody clearly shows a gradient that is expressed in the germinative zone and in the cells of the inner ganglion and nuclear layers. The eyeball and particularly the retina in salmon alevins are an example of neuronal plasticity and neurogenesis.

KEY WORDS: Eyeball; Orbit; Retina; Salmo salar; Hypoxia; HIF1 $\alpha$; Shh.

\section{INTRODUCTION}

Teleost fish, unlike mammals and other vertebrates, have the capacity to regenerate various tissues, including the vertebral column (Hernández \& Rojas, 2013), and the eyeball with all its structures (Carter-Dawson \& Lavail, 1979). The new neurons generated by the stem cells of the retina are continually added to its strate during growth (Easter \& Hitchcock, 2000; Otteson \& Hitchcock, 2003). The rod progenitors not only produce rods but when faced with injury can regenerate various cell subtypes in the retinal tissue (Otteson \& Hitchcock). It has also been shown that there is an ontogenetic change to adapt to different environments during their lifecycle. All this occurs in natural life conditions and not in captivity or altering their habitat.

During their lifecycle, fish can change their habitat and go through different development phases that in turn have different light environments. Such changes are often related to the remodeling of processes in the organism known as metamorphosis (Browman \& Hawryshyn, 1992; Alexander et al., 1994). On the other hand, animals that live

\footnotetext{
* PhD in Morphological Sciences Program, Universidad de La Frontera, Temuco, Chile.

** Development Anatomy and Biology Program, ICBM, Faculty of Medicine, Universidad de Chile, Santiago, Chile.

**** Center of Excelence for Morphological and Surgical Studies (CEMyQ), Universidad de La Frontera, Temuco, Chile.

***** Center of Biomedical Sciences, Universidad Autónoma de Chile, Chile.
} 
in an aquatic environment undergo a variable oxygen stress, which enables the hypoxia-inducible factor (HIF) to be assessed and relate it to the hypoxia levels (Rojas et al., 2007). Fish can be divided into two groups: hypoxia-sensitive and hypoxia-resistant. Salmon belong to the former group and the shark and carp to the latter (Hernández, 2011).

The alevin and fry stages take place in freshwater, and the salmon then migrate to the sea and there is ontogenetic remodeling known as smoltification, which entails shifts in the visual pigments from porphyropsin dominant to rhodopsin dominant. There is also a loss of ultraviolet-sensitive photoreceptors (Browman \& Hawryshyn; Alexander et al.).

The visual pigments in the retina absorb light and start a phototransduction cascade which leads to neuronal signaling and ultimately the fish's behavior. The visual pigments are light-sensitive molecules that are found in external segments of the photoreceptors and consist of a vitamin A-based chromophobe united to an opsin protein, starting a phototransduction cascade that leads to neuronal signaling and finally affects the fish's behavior. One example is the adaptive visual changes of flatfish, which undergo vertical migration during the ontogeny that is associated with photic changes (Beaudet \& Hawryshyn, 1999).

Effects of hypoxia on development. The aquatic environment is characterized by having a marked temporary and spatial heterogeneousness of the availability of oxygen. The quantity of oxygen contained in a certain volume of water is only $1 / 30$ parts of that contained in the same volume of air. Moreover, as the temperature and salinity increase, the quantity of oxygen that can be dissolved in water decreases. Finally, the oxygen diffusion rate in water is 10,000 times slower than in air (Nikinmaa \& Rees, 2005).

Despite these adaptive responses, most fish during their early life are very sensitive to low levels of dissolved oxygen, and such sensitivity varies according to the development stage (Shang \& Wu, 2004; Podrabsky et al., 2007). It has been shown that in fish hypoxia retards growth, induces apoptosis, lowers the success of fertilization and hatching and the survival of the larvae and leads to vertebral column deformity (Castro Sánchez et al., 2011). Sublethal levels of hypoxia can also increase deformity by over $77 \%$ during fish embryonic development (Shang \& Wu).

Fish have developed mechanisms of adapting to hypoxic environments. The hypoxia-inducible factor (HIF1) is a system that regulates the gene expression depending on the oxygen levels (Semenza, 2000; Vuori et al., 2004; Rojas et al., 2007; Rytkönen et al., 2007), which mediates the adaptive responses to hypoxia by means of the transcription gene expression, among others, for erythropoietin and the vascular endothelial growth factor (VEGF), thereby increasing the systematic transport of oxygen and local vascularization (Nikinmaa \& Rees; Nanka et al., 2006).

Prior studies have been conducted on the changes caused by hypoxia on the vertebral column (Hernández \& Rojas). The gills of Salmo salar in the alevin stage with the yolk sac in hypoxia and normoxia have also been studied. Slight and moderate hypoxia levels lead to histological changes in the gills, mainly at vascular level, which could be part of the adaptive response of this species to the lower availability of dissolved oxygen (Peñailillo, 2012).

Changes in the vertebral column of salmon alevins in normoxia and hypoxia have also been studied, with it being observed that hypoxia triggers congenital vertebral column deformity (Castro Sánchez et al.). Due to the presence of this deformity, we propose conducting a morphological study of the eyeball, the orbit and retina under hypoxic conditions in Atlantic salmon (Salmo salar) alevins.

For the structuring of any corporal tissue there must be a series of processes in an ordered and structured way. This is known as pattern formation (Wolpert, 2009) and the cells gain positional information, attaining certain spatial organization within the organism. The morphogens act as positional signals that control the cell destination of the embryo. The morphogen concept is understood to be the differential gene expression that is dependent on the concentration (Rojas et al., 2014). In the case of zebrafish, the expression of Sonic Hedgehog ( $\mathrm{Shh}$ ) in eyeball development is considered, just as in other vertebrates (Stenkamp \& Frey, 2003).

Topography of the retina of vertebrates. The retina covers the choroidal membrane internally. It is divided into two portions, the retinal pigment epithelium next to the choroidal membrane and the neurosensory retina next to the vitreous. The zebrafish (Danio rerio) and goldfish (Carassius auratus) are used as development models of the retina of vertebrates. During the development of the retina in the zebrafish and goldfish cones and rods appear simultaneously (Stenkamp et al., 1996).

There are few studies on the retina of the salmon alevin (a species of great economic importance for Chile). The objectives of this study were to: 1) Compare the morphological characteristics and the axial diameter of the eyeball and orbit of fish subject to hypoxia and normoxia. 2) Describe the retina of the salmon alevin. 3) Assess the 
presence and distribution of the HIF1 $\alpha$ protein in hypoxic salmon alevins. 4) Determine the expression of the Shh morphogen in salmon alevins exposed to different times of hypoxia.

\section{MATERIAL AND METHOD}

The study was conducted on about 1,000 Salmo salar (alevins with their yolk sac). The ova of the alevins were cultured at the Aquaculture Study Center of the University of Chile (Castro, Chiloé) in a continuous water flow $\left(9^{\circ} \mathrm{C}\right.$ and $100 \% \mathrm{SatO}_{2}$, a controlled environment with 6 measurements a day using the OxyGuard ${ }^{\circledR}$ device).

$\mathbf{1}^{\text {st }}$ stage. At hatching (495 UTAs) the salmon alevins were separated into two equal groups, one in normoxia (100\% $\left.\mathrm{SatO}_{2}\right)$ and the other in hypoxia $\left(60 \% \mathrm{SatO}_{2}\right.$, and this condition was attained by slowing down the water flow). At days two, four, and eight after hatching $(513,531,549$ and 567 UTAs, respectively), 40 fish from each group (normoxia and hypoxia) were anesthetized with $5 \%$ benzocaine (BZ-20 ${ }^{\circledR}$, Veterquímica), then fixed in buffered $10 \%$ formalin and processed to undertake the techniques of HIF $1 \alpha$ that is a hypoxia sensor.

$\mathbf{2}^{\text {nd }}$ stage: 20 salmon alevins from each hypoxia group were transferred to normoxia (at days two, four, and eight after hatching) and another 20 fish were kept in hypoxia (chronic). They were all euthanized at 950 UTAs $( \pm 2$ months after hatching, time of the first feed). The morphometric characteristics of the eyeball of this group were analyzed under a stereo microscope (Stemi DV4, Zeiss). A control group maintained in continuous normoxia and another in continuous hypoxia was considered (Table I). The research protocol was approved by the Scientific Ethical Committee of Universidad de La Frontera, Chile.

To achieve the objective, the following was necessary:

1. To describe the morphological characteristics and compare the axial diameter of the eyeball of fish in hypoxia and kept in normoxia, work was done with the second experimental group and the diaphanization (double-stain) technique was undertaken according to Hanken \& Wassersug (1981). 8 fish from each group were put in protein digestion (trypsin) and exposed to the Alcian blue stain, which stains the cartilaginous tissue blue. The fish were examined with a stereo microscope (Stemi DV4, Zeiss) and the morphology of the periocular cartilage was analyzed, separating those with irregularities and undulations. The lineal measurements of the dorsoventral and nasal-temporal diameters were taken using the software Image Tool 3.0. [online] (UTHSCSA, 2002) and they were then averaged.

2. To describe the constitution of the salmon alevin retina 10 fish from each group were used, fixed in $10 \%$ buffered formalin, then included in solid paraffin, sectioned at $5 \mathrm{~mm}$ with a Microm (HM315R) microtome and processed with routine techniques for the Alcian blue and hematoxylin-eosin. The thickness of the two layers of the retina was obtained by taking the mean of 10 measurements made at the central retina, avoiding the bias of the single measurement in a structure that has variations. The transversal cuts were made at the height of the orbit. The thickness of the layers was measured with the AxioVision program.

3. To assess the presence and distribution of the Hif $1 \alpha$ protein in normoxic and hypoxic salmon alevins, work was done with the first group of fish. Transversal sections were taken from the salmon alevins (5 $\mathrm{mm}[\mathrm{J} 1]$ thick) at the height of the orbit, mounted on xylan-coated slides and then treated using the immunohistochemical method for detecting HIF-1 $\alpha$ (antibody H-206, Santa Cruz Biotechnology 10790) 1:50. The sections were made with the Microm (HM315R) microtome, which were placed on slides with a positive charge (Citoglas). Five sections were placed on each slide and 2 slides per salmon alevin. The antigens were recovered in a vaporizer for $40 \mathrm{~min}$, with the cuts submerged in Antigen unmasking solution (Vector). The endogenous peroxidase was blocked with hydrogen peroxide in methanol and non-specific blocking of proteins with $3 \%$ PBS+BSA. To detect the primary antibody this was incubated with polymer conjugated with the anti-rabbit antibody and HRP for $15 \mathrm{~min}$. Diaminobenzidine (DAB, Vector Labs) was used as the HRP substrate. The negative control arose from undertaking the full immunohistochemical technique but without considering the primary antibodies. The skin of the same salmon alevins was considered as the positive control.

Table I. Research protocol followed by number of days in hypoxia, UTAs and number of fish.

\begin{tabular}{lccc}
\hline Days in hypoxia & UTAs when transferred to normoxia & UTAs on sampling & n of fish \\
\hline Control (0 day of hypoxia) & Continuous normoxia & 950 & 20 \\
2 days & 513 & 950 & 20 \\
4 days & 531 & 950 & 20 \\
8 days & 567 & 950 & 20 \\
Continuous hypoxia & Continuous hypoxia & 950 & 20
\end{tabular}


4. To assess the detection of a signaling protein by means of the anti-Shh antibody, the salmon alevins were fixed in $10 \%$ buffered formalin and included in paraffin like the previous group. Five millimeters thick sections were obtained and placed on slides with a positive charge (Citoglas). Likewise, Five sections were placed on each slide considering a total of two slides per salmon alevin. The antigens were recovered in a vaporizer for 40 minutes, with the cuts submerged in Antigen unmasking solution (Vector). The endogenous peroxidase was blocked with hydrogen peroxide in methanol and non-specific blocking of proteins with $3 \%$ PBS+BSA. A 1:100 dilution in PBS was used for the incubation with the primary antibody Shh (Santa Cruz, H-160, rabbit). To detect the primary antibody this was incubated with polymer conjugated with the antirabbit antibody and HRP for 15 minutes. Diaminobenzidine (DAB, Vector Labs) was used as the HRP substrate. The negative control arose from undertaking the full immunohistochemical technique but without considering the primary antibodies. The notochord was considered as the positive control.

Statistical analysis. The values obtained for the quantitative variables (orbit diameter, thickness of retina layers, number of cells immunomarked for HIF-1 $\alpha$ and Shh) were processed and analyzed by means of the arithmetical mean and the standard deviation.

\section{RESULTS}

Comparison of the axial diameters of the eyeball and orbit in fish subject to hypoxia and maintained in normoxia.

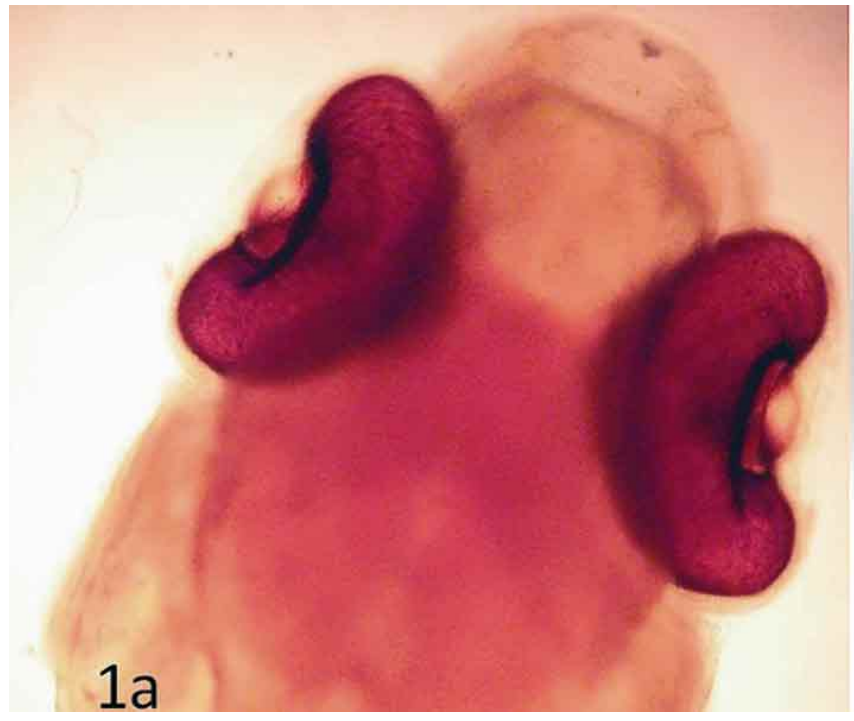

In the first group the salmon alevins had pigmented eyeballs of a greater diameter (Fig. 1a). They had an optic cup of an embryonic shape and a choroidal fissure characteristic (Fig. 1b). A thicker eyeball was observed in the nasalventral zone which corresponds to the germinal zone (GZ) of the retina.

In the second group, using the diaphanization (double-stain) technique it could be seen that the eyeball was completely protected by a cartilaginous orbit (Figs. 2 and 3). This had changes in size and shape in the fish subject to chronic hypoxia. There was a decrease in the diameter (from $2 \mathrm{~mm}$ to $1.3 \mathrm{~mm}$ ) and loss of regularity of the hyaline cartilage, which had folding and undulations (Table II).

Table II. Nasal-temporal and dorsoventral diameter of salmon alevins maintained in normoxia and hypoxia.

\begin{tabular}{lcc}
\hline & NT & DV \\
\hline Control & $1.9 \pm 0.06$ & $1.65 \pm 0.14$ \\
Day 2 & $1.9 \pm 0.19$ & $1.77 \pm 0.17$ \\
Day 4 & $1.9 \pm 0.09$ & $1.71 \pm 0.14$ \\
Day 8 & $1.84 \pm 0.6$ & $1.55 \pm 0.25$ \\
Chronic & $1.3 \pm 0.1$ & $0.97 \pm 0.17$ \\
\hline
\end{tabular}

Morphological constitution of the alevin retina. There were two different parts in the retina of alevins: the central zone of the retina and the peripheral retina (Fig. 4a, b, c and d). The central zone of the retina is stratified in cell and plexiform layers. The pigment epithelium and the neurosensory retina can be differentiated. The pigment epithelium and the layer of the photoreceptor segments have melanin pigments and both form the pigment layer.

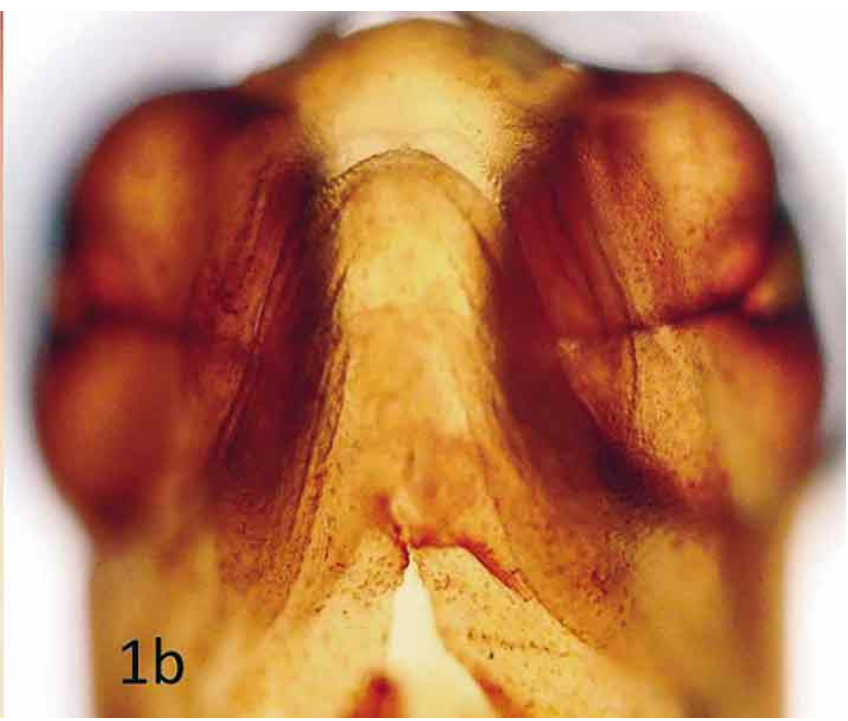

Fig. 1. Salmon alevins after hatching. a) Dorsal view, b) Ventral view. Eyeballs with a choroidal fissure were observed. 


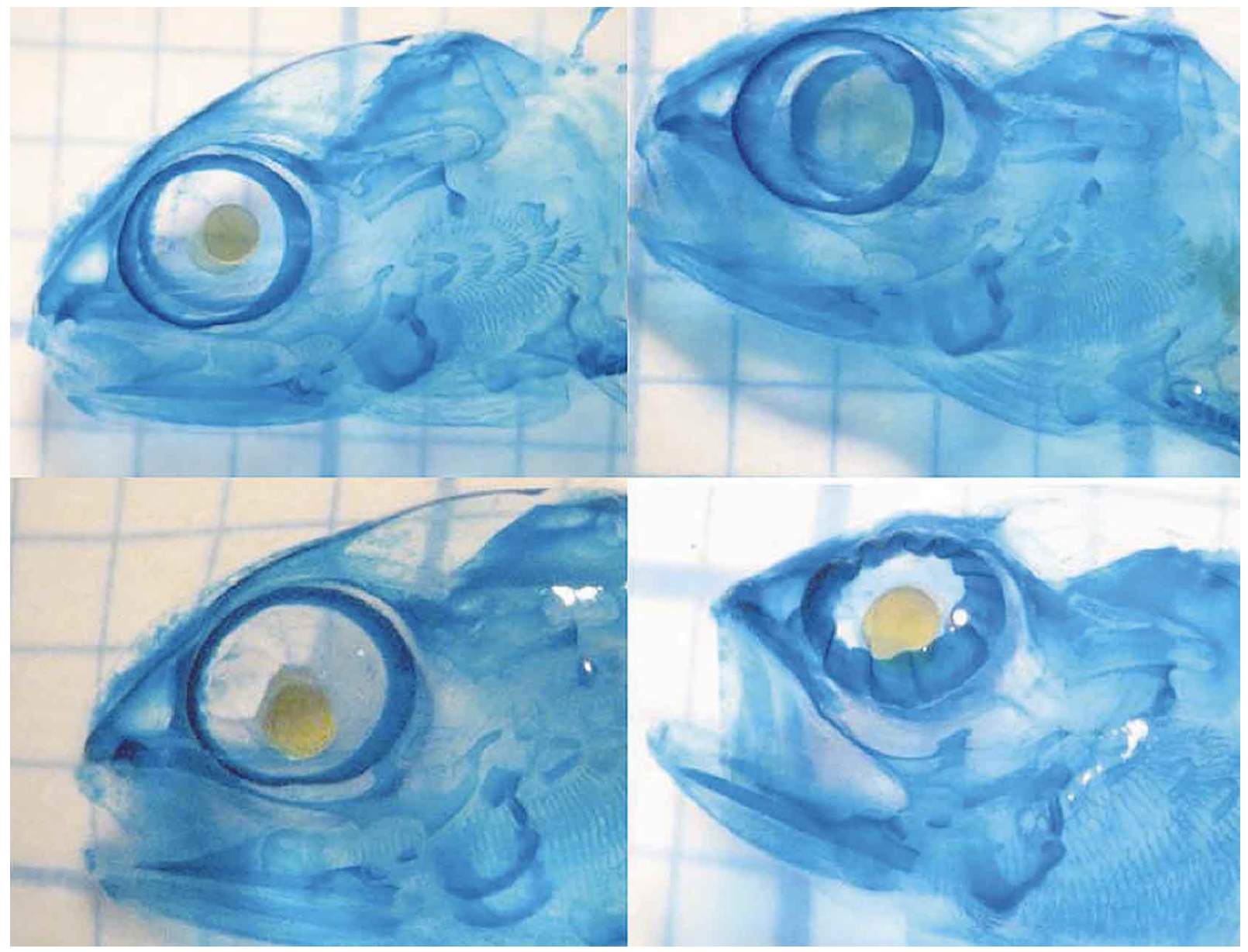

Fig. 2. a) Salmon alevins after 2 days in hypoxia, b) 4 days in hypoxia, c) 8 days in hypoxia and d) chronic hypoxia. Diaphanization stain and stain for cartilage. Haenckel \& Wassersug.

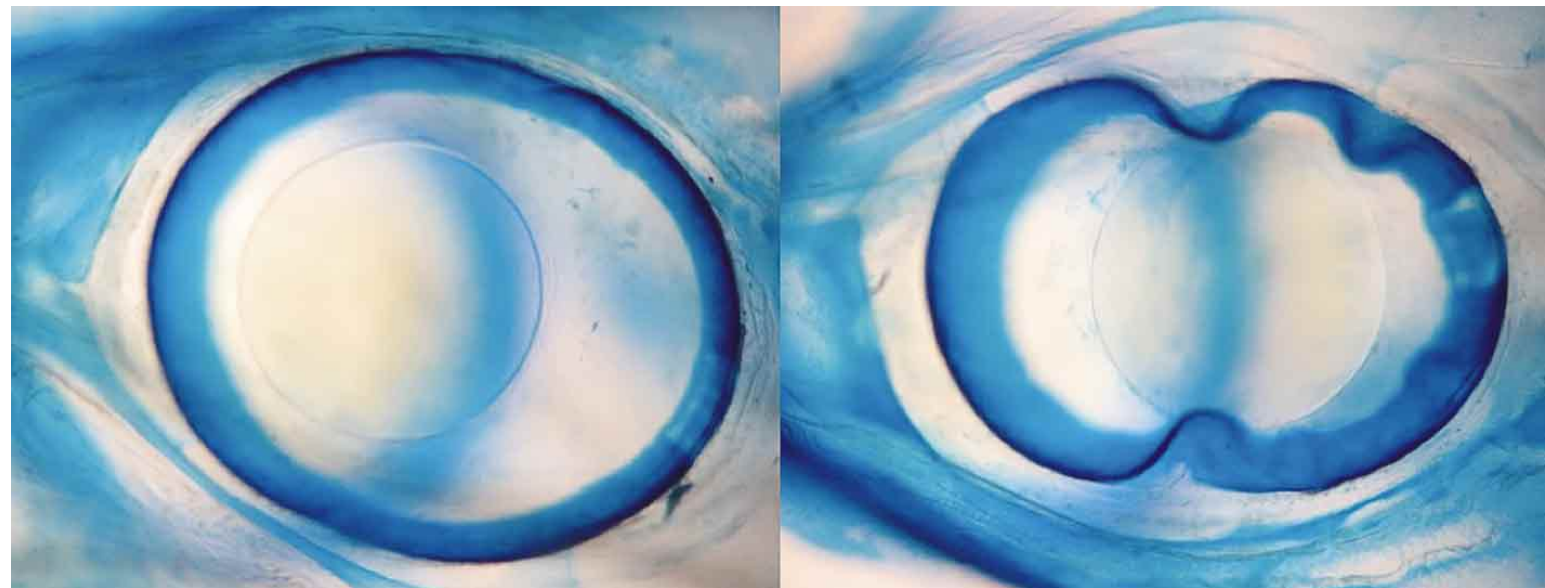

Fig. 3. Cartilaginous orbit. a) Normal salmon alevins in normoxia, b) Orbit of salmon alevins maintained for eight days in hypoxia.

The outer limiting membrane was imperceptible. The outer nuclear layer is made up of cell bodies of cones and rods. The outer plexiform layer was unperceivable in these alevins. The somas of all the retinal interneurons are in the inner nuclear layer and it is the thickest with two zones, one very dense and the other more lax. The inner plexiform layer 


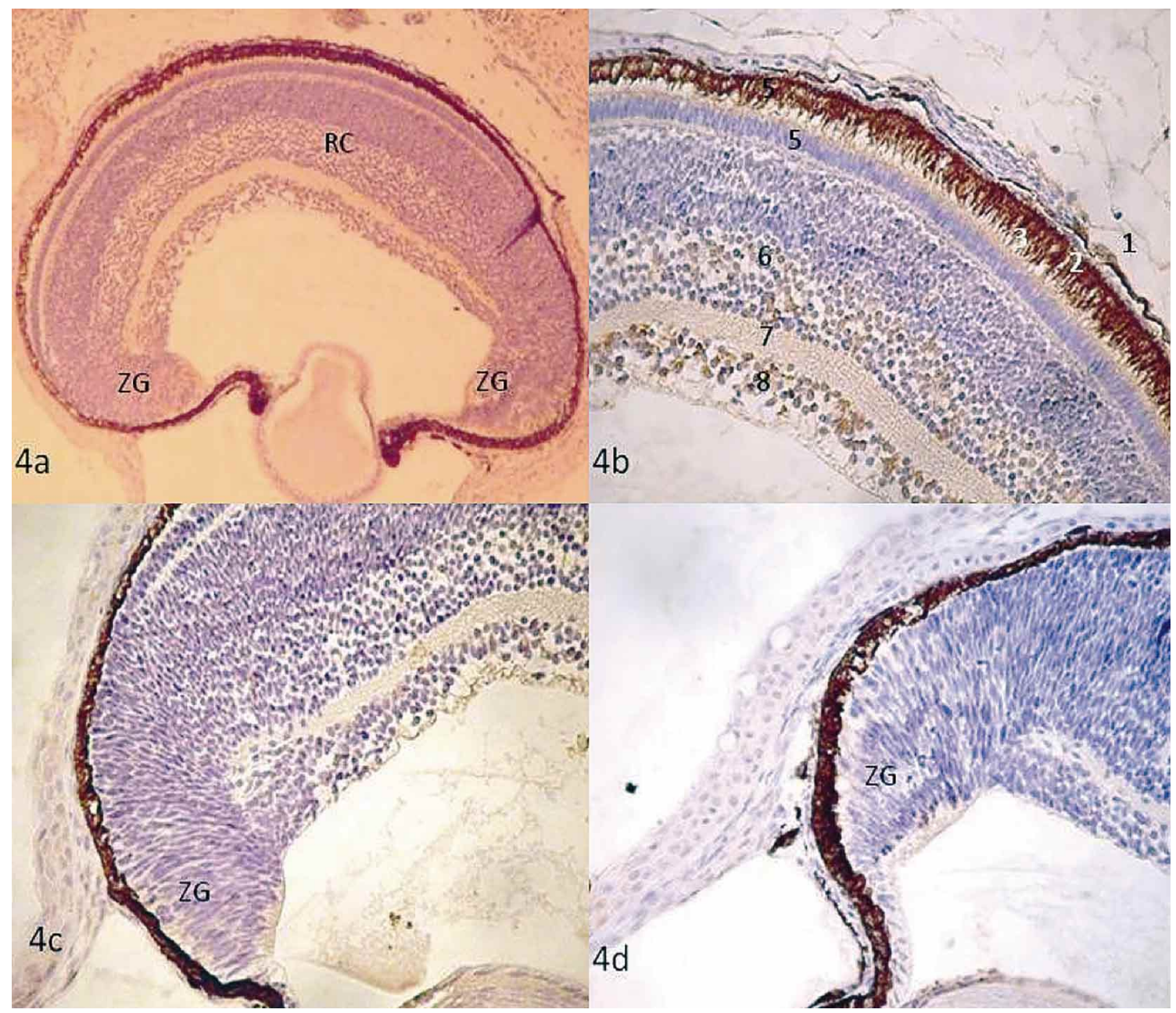

Fig. 4. Retina of alevins subject to $60 \%$ oxygen saturation. a) Panoramic view of the alevin retina. ZG: germinative zone, RC: central retina. b) Central retina layers. 1: pigment epithelium, 2: layer of photoreceptor segments, 3: outer limiting membrane. 4: outer nuclear layer, 5: outer plexiform layer, 6: inner nuclear layer, 7: inner plexiform layer, 8: layer of the ganglion cells, HIF $1 \alpha, 400 X$. Positive immunostaining on the inner nuclear layers and layer of ganglion cells. c) Non-sensory retina. ZG: technical germinative layer: HIF $1 \alpha, 400 X$. d) Negative control without the anti-HIF $1 \alpha$ antibody. ZG: germinative layers. 400X.

contains the axons. The ganglion cell layer comprises the somas of the ganglion cells. The layer of the optic nerve fibers is made up of the axons of the ganglion cells and the glial cells. Lastly, the location of the inner limiting membrane is virtually unperceivable (Fig. 4 a, b and c).

Differences were found between the central zone of the retina and the peripheral retina (Fig. $4 \mathrm{c}$ and d), therefore the outer limiting membrane, the outer nuclear layer and the outer plexiform layer that were present in the central zone are not seen in the peripheral germinative zone. The peripheral germinative zone was observed to be a pseudostratified epithelium. There was a transition zone where lamination had not been established yet and the cells were fusiform and were in the process of differentiation.
There is a clear continuity between the peripheral germinative zone and the ganglion layer (Fig. $4 \mathrm{c}$ and d).

Evaluation of the retina of hypoxic alevins using the HIF $1 \alpha$ antibody as a marker. When using the anti-HIF $1 \alpha$ antibody as a hypoxia sensor, only positive immunostaining was observed in the central retina, in the groups subject to hypoxia (Fig. 4a and 4b), and the germinative zone had no positive staining (Fig. $4 \mathrm{c}$ and $4 \mathrm{~d}$ ) and Table III.

The inner and ganglion nuclear layers of the central retina tested immunopositive to HIF $1 \alpha$ (Fig. 5). The marks were observed in the nucleus and the cytoplasm. The immunostaining was greater when the alevins were two days in hypoxia and was minimal when the hypoxia was chronic. 


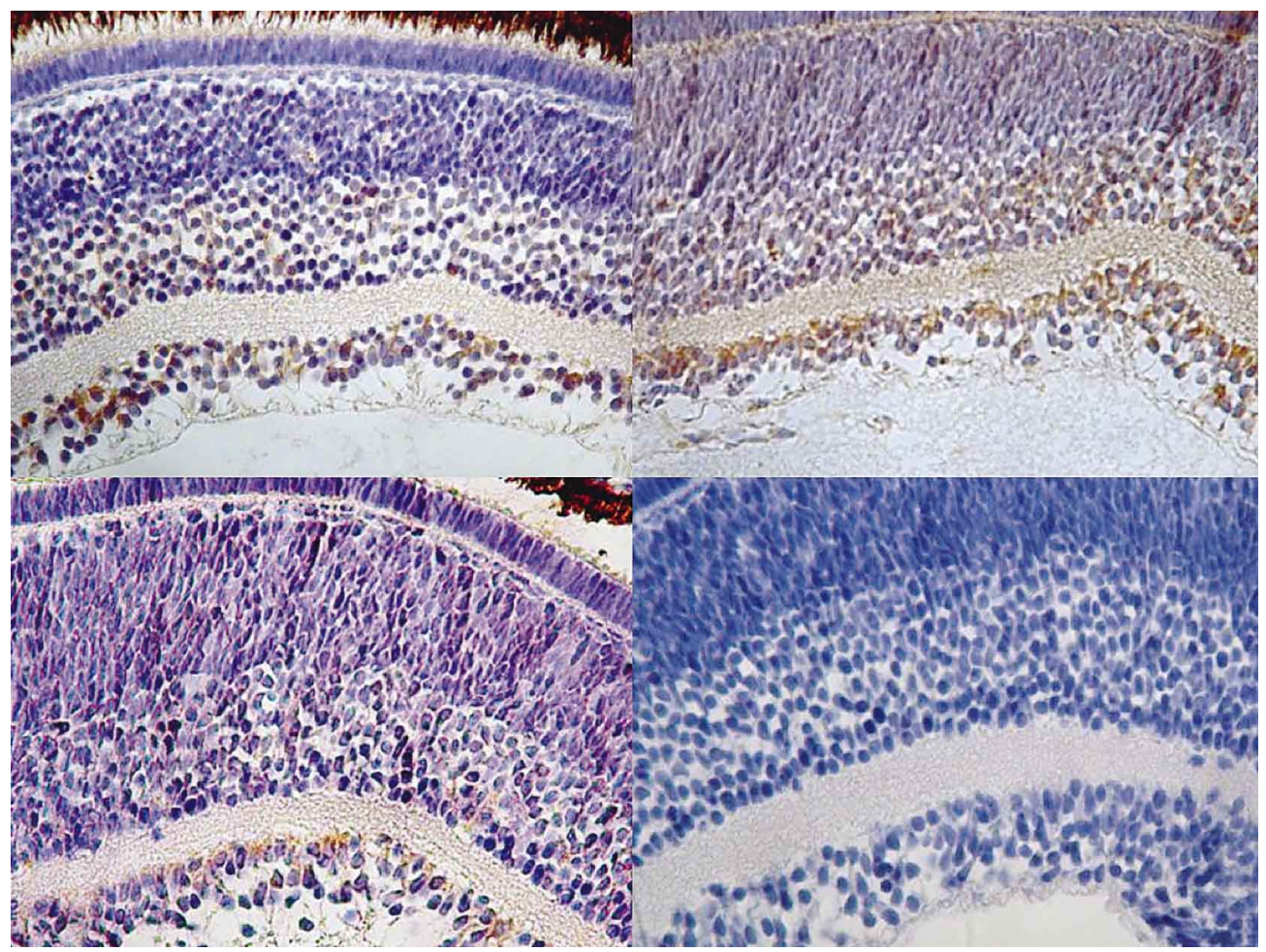

Fig. 5. Central retina of alevins subject to $60 \%$ oxygen saturation. a) 2 days, b) 4 days and c) 8 days in hypoxia. Positive immunostaining in the inner nuclear and ganglion cell layers. HIF $1 \alpha, 400 X$. d) Negative control without the anti-HIF $1 \alpha$ antibody. $400 X$.

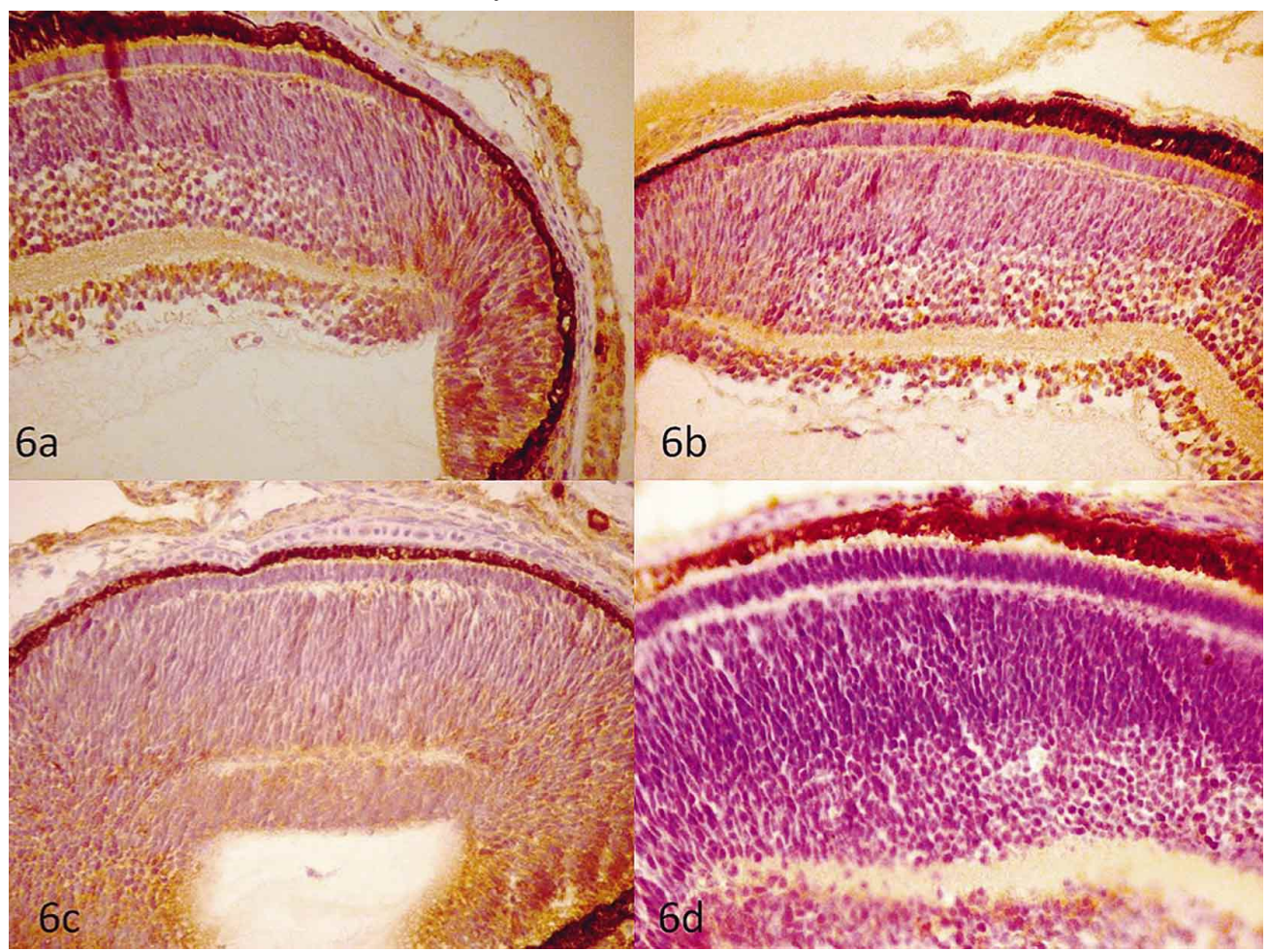

Fig. 6. a) Shh protein immunostaining. a and b) Retina of alevins after 2 days of hypoxia. The cells of the ganglion layer and the more lax zone of the inner nuclear layer and GZ are positive, the periocular cartilage is negative. c) Shows alevins kept in chronic hypoxia. The germinative zone is intensely positive. d) Shows chronic hypoxia. The cells of the ganglion layer are positive. 
Table III. Quantification of immunopositive cells in the retina of alevins in the groups subject to hypoxia for 2,4 , and 8 days, and chronic hypoxia.

\begin{tabular}{lc}
\hline Group & Positive cells \\
\hline 2 days in hypoxia & $65 \pm 26$ \\
4 days in hypoxia & $27 \pm 14$ \\
8 days in hypoxia & $32 \pm 8.5$ \\
Chronic & $13+13$ \\
\hline
\end{tabular}

Shh expression in the retina of hypoxic alevins. The antiShh antibody was suitable to assess the morphogen in these fish. The Shh expression was positive in the proliferative marginal zone (GZ). It was also positive in the nucleus and cytoplasm of the cells of the ganglion and inner nuclear layers. The expression was positive in alevins subject to two days in hypoxia, but the alevins subject to chronic hypoxia had a lower expression in the inner nuclear layer, with continued intense marking in the germinative zone. Figs. 6.

\section{DISCUSSION}

Comparison of the axial diameters of the eyeball and orbit of fish subject to hypoxia and kept in normoxia. In the first group, the alevins of group 1 (days two, four and eight after hatching) that were taken out of hypoxia to normoxia had, using the diaphanization technique, a larger eyeball with the optic cup having an embryonic shape, even a choroidal fissure. The greatest thickness was observed in the nasalventral zone corresponding to the PGZ. The alevins in this stage remain immobile at the bottom of the water (Hernández \& Rojas) and feed from the yolk sac like other species.

In the second group (950 UTA) that was maintained in chronic hypoxia, it was observed, using the diaphanization technique, that the periocular cartilage that covers the eye changes in shape and size. In the eyeball there is a decrease in the nasal-temporal and dorsoventral diameter (from $2 \mathrm{~mm}$ to $1.3 \mathrm{~mm}$ ) and a loss of regularity of the hyaline cartilage, where folding and undulations were observed. This is similar to what happens in other cartilaginous structures of the vertebral column of the alevin which, subject to hypoxia, can trigger vertebral column deformity (Castro Sánchez et $a l$. .). In this group, the yolk sac is smaller and the alevin can swim on the surface.

Description of the retina of the salmon alevin. There were two different parts in the retina of all the alevins: 1) the peripheral retina and 2) the central zone. The peripheral retina has a proliferative germanitive zone (PGZ), similar to that described by Ottenson \& Hitchcock, who said that all the retinal cell types except the rods are formed from the PGZ. In the adult retina Stenkamp (2011) says that new cells are generated from two retinoblast populations, the PGZ and the lineage of rod progenitors. Queiroz (2007) and Sánchez González (2009) say that from the PGZ concentric rings of cells are added to the retina that mature and are different, so the cells that are in the more peripheral regions of the retina will be the youngest. The new layers shift to those already formed, with there being a transition zone where the lamination is still not established as the cells are differentiating.

The retina is stratified into layers, but some of these are very difficult to observe (outer plexiform). This is very different from what occurs with the European seabass (Queiroz), which on hatching has a very undifferentiated retina without any organization into layers. The recently hatched goldfish (Carassius auratus) has a laminated neural retina but the photoreceptors are not very differentiated (Johns, 1982). Other teleost fish like the striped trumpeter (Latris lineata) have a totally undifferentiated retina on hatching but as of the third day a clear stratification emerges (Cobcroft \& Pankhurst, 2003). According to Queiroz, all the species have their retinas organized into cell layers but the formation timeline depends on each species. The optic cup aspect with embryonic characteristics has only been reported in salmonids and a choroidal fissure is recognized, a central retina zone and another peripheral one.

Immunohistochemically assess the retina of hypoxic alevins using HIF- $1 \alpha$ as a sensor. The central retina of alevins that were cultured with $60 \%$ of $\mathrm{O}_{2}$ saturation for two, four or eight days had positive immunostaining when analyzed with the anti-HIF1 $\alpha$ antibody and hypoxia sensor. The layers marked positive in the retina were the inner nuclear layer and the ganglion layer, reaching the maximum when the alevins were two days in hypoxia and minimum when the hypoxia is chronic. Nevertheless, the alevins subject to chronic hypoxia had anatomical deformity of the eyeball and periocular cartilage. The marking in the retina is similar to what occurs in the nerve cells of the vertebral column (Castro Sánchez et al.).

Recognize the location of the Shh expression in the retina of hypoxic alevins. The anti-Shh antibody has reactivity in teleost fish and clearly shows a gradient of the morphogen, which is expressed in the germinative zone that corresponds to the pluripotent cells that will give rise to new cells. It was also possible to find them in the cells of the ganglion and inner nuclear layers. This is comparable with that described by Jensen \& Wallace (1997), who observed the Shh expression in cells of the ganglion layer and inner nuclear layer of the mouse by means of in situ hybridization. In the 
zebrafish, Shh is expressed in the pigment epithelium located in the ventronasal region ( $\mathrm{Hu} \&$ Easter, 1999) and extends through the epithelial lamina. Neurogenesis and cell differentiation of the retina in teleost fish follows a stereotyped pattern during the development of the eyeball. It starts in the ventronasal retina, followed by asymmetric centrifugal propagation, so that cells are formed in the nasal retina and it then occurs in the temporal retina (Larison \& Bremiller, 1990; Raymond et al., 1995; Hu \& Easter). The hedgehog $(\mathrm{Hh})$ gene of the family of signaling proteins that are secreted participates in the pattern of forming the retina of the zebrafish. One of the first signaling functions of Shh is to induce tissue for the optic stalk at the expense of the neural tissue of the retina (Perron et al., 2003). A short time later, neurogenesis is started in the retina by a signal that is sent from the optic stalk (Masai et al., 2000). The first neurons that arise in the retina are the ganglion cells and this is the Shh expression.

The eyeball, and particularly the retina, of teleost fish are an important model for the study of the ontogeny, neuronal plasticity and neurogenesis. This neurogenesis in the retina of fish facilitates cell restructuring throughout the ontogeny, which potentially allows for optimization of the visual system for changes the visual demands. This study might be useful to facilitate diagnosis in eye pathologies in the salmon farming industry and could also lead to better knowledge of how tissue regeneration occurs. On the other hand, with subsequent studies neurogenesis of fish retinae could be extrapolated to the treatment of human eye diseases.

PELLÓN, M.; ROJAS, M.; SAINT-PIERRE, G.; HARTLEY, R. \& DEL SOL, M. Morfología del bulbo ocular, órbita y retina de alevines del salmón del atlántico (Salmo salar) bajo condiciones hipóxicas. Int. J. Morphol., 34(1):320-329, 2016.

RESUMEN: Se ha demostrado que la hipoxia retarda el crecimiento de los peces, reduce la supervivencia de sus larvas, deforma su columna vertebral, pero a pesar de esto, este pez teleósteo tiene la capacidad de regenerar completamente muchos de sus tejidos, en particular la retina. Como no existe suficiente información sobre los efectos de la hipoxia en el bulbo ocular, la órbita y retina del salmón del Atlántico (Salmo salar), los objetivos de este trabajo fueron: 1) Comparar los cambios morfológicos del bulbo ocular del pescado sujetos a hipoxia y normoxia; 2) Determinar los cambios en la estructura de la órbita; 3 ) Describir la retina de los alevines de salmón; 4) Reconocer las células hipóxicas utilizando el anticuerpo anti-Hifl $\alpha$ en la retina de alevines como un sensor; 5) Determinar la expresión morfogenética de Shh en alevines expuestos a diferentes momentos de hipoxia. Alrededor de 1.000 alevines Salmo salar se colocaron en un flujo continuo de agua a $9{ }^{\circ} \mathrm{C}$, con $100 \%$ de $\mathrm{SatO}_{2}$ y otros alevines se mantuvieron con una hipoxia de $60 \% \mathrm{SatO}_{2}$. Estos últimos fueron trasladados a normoxia (en los días dos, cuatro y ocho después de la eclosión). Un grupo control se mantuvo a normoxia continua y otro grupo a hipoxia continua. Todos los alevines se sacrificaron a 950 UTA (+ dos meses después de la eclo- sión). Se realizcón una diafonización (doble tinción), de acuerdo con la técnica de Hanken \& Wassersug, para describir la morfología del cartílago periocular y para medir el diámetro ocular. Se utilizaron el anticuerpo anti-Hif1 $\alpha$ a una dilución 1:50, y el anticuerpo anti-Shh a una dilución de 1:100. Los alevines después de la eclosión presentaron grandes bulbos oculares, con la copa óptica con forma embrionaria, incluso una fisura coroidea. El mayor espesor se observó en la zona ventral nasal que corresponde a una zona de células pluripotentes. El aspecto de la copa óptica con características embrionarias sólo se ha informado en los salmónidos. La retina central de los alevines fueron cultivadas con una saturación de $60 \%$ de $\mathrm{O}_{2}$ para dos, cuatro y ocho días, y presentó inmunotinción positiva cuando se analizó con el sensor de hipoxia, el anticuerpo anti-HIF1 $\alpha$. El ganglio interior y las capas nucleares presentaron células immunopositivas, con los niveles más altos en los alevines con dos días de hipoxia y niveles más bajos en hipoxia crónica. Sin embargo, en éste último caso los alevines presentaron una deformación anatómica del bulbo ocular y el cartílago periocular. El anticuerpo anti-Shh mostró claramente un gradiente expresado en la zona germinativa y en las células del ganglio interior y las capas nucleares. El bulbo ocular y en particular la retina en alevines de salmón son un ejemplo de plasticidad neuronal y neurogénesis.

PALABRAS CLAVE: Globo ocular; Orbita; Retina; Salmo salar; Hipoxia; HIF1 $\alpha$; Shh.

\section{REFERENCES}

Alexander, G.; Sweeting, R. \& Mckeown, B. The shift in visual pigment dominance in the retinae of juvenile coho salmon (Oncorhynchus kisutch): An indicator of smolt status. J. Exp. Biol., 195(1):185-97, 1994.

Beaudet, L. \& Hawryshyn, C. W. Ecological Aspects of Vertebrate Visual Ontogeny. In: Archer, S. N.; Djamgoz, M. B. A.; Loew, E. R.; Partridge, J. C. \& Vallerga, S. (Eds.). Adaptive Mechanisms in the Ecology of Vision. London, Springer-Science+Business Media, B.V., 1999. pp.413-37.

Browman, H. I. \& Hawryshyn, C. W. Thyroxine induces a precocial loss of ultraviolet photosensitivity in rainbow trout (Oncorhynchus mykiss, Teleostei). Vision Res., 32(12):2303-12, 1992.

Carter-Dawson, L. D. \& LaVail, M. M. Rods and cones in the mouse retina. II. Autoradiographic analysis of cell generation using tritiated thymidine. J. Comp. Neurol., 188(2):263-72, 1979.

Castro Sánchez, R.; Bustos Obregón, E. \& Rojas Rauco, M. Hypoxia is like an ethiological factor in vertebral column deformity of salmon (Salmo salar). Aquaculture, 316(1-4):13-9, 2011.

Cobcroft, J. M. \& Pankhurst, P. M. Sensory organ development in cultured striped trumpeter larvae Latris lineata: implications for feeding behaviour. Mar. Freshw. Res., 54(5):669-82, 2003.

Easter, S. S. \& Hitchcock, P. F. Stem cells and regeneration in the retina: What fish have taught us about neurogenesis. Neuroscientist, 6(6):45464, 2000.

Hanken, J. \& Wassersug, R. The visible skeleton. A new double-stain technique reveals the native "hard" tissues. Funct. Photogr., 16:22-6, 1981. 
Hernández, H. \& Rojas, M. Development of spinal cord of the salmon (Salmo salar) during the period post eclosional. Int. J. Morphol., 31(1):172-6, 2013.

Hernández, H. Efecto de la Hipoxia en el Desarrollo de la Médula Espinal en Salmón (Salmo salar). Tesis para obtener el grado de Magister en Ciencias Biológicas. Santiago de Chile, Facultad de Medicina, Universidad de Chile, 2011

Hu, M. \& Easter, S. S. Retinal neurogenesis: the formation of the initial central patch of postmitotic cells. Dev. Biol., 207(2):309-21, 1999.

Jensen, A. M \& Wallace, V. A. Expression of Sonic hedgehog and its putative role as a precursor cell mitogen in the developing mouse retina. Development, 124(2):363-71, 1997.

Johns, P. R. Formation of photoreceptors in larval and adult goldfish. $J$. Neurosci., 2(2):178-98, 1982

Larison, K. D. \& Bremiller, R. Early onset of phenotype and cell patterning in the embryonic zebrafish retina. Development, 109(3):567-76, 1990.

Masai, I.; Stemple, D. L.; Okamoto, H. \& Wilson, S. W. Midline signals regulate retinal neurogenesis in zebrafish. Neuron, 27(2):251-63, 2000

Nanka, O.; Valásek, P.; Dvoráková, M. \& Grim, M. Experimental hypoxia and embryonic angiogenesis. Dev. Dyn., 235(3):723-33, 2006.

Nikinmaa, M. \& Rees, B. B. Oxygen-dependent gene expression in fishes. Am. J. Physiol. Regul. Integr. Comp. Physiol., 288(5):R1079-90, 2005.

Otteson, D. C. \& Hitchcock, P. F. Stem cells in the teleost retina: persistent neurogenesis and injury-induced regeneration. Vision Res., 43(8):92736, 2003.

Peñailillo, P. Hif lalfa como Marcador Molecular para el Estudio de Branquias y su Asociación con Hipoxia en Salmón Salmo salar. Programa de Magister en Ciencias Biológicas. Santiago de Chile, Facultad de Medicina, Universidad de Chile, 2011.

Perron, M.; Boy, S.; Amato, M. A.; Viczian, A.; Koebernick, K.; Piler, T. \& Harris, W. A. A novel function for Hedgehog signalling in retinal pigment epithelium differentiation. Development, 130(8):1565-77, 2003.

Podrabsky, J. E.; Lopez, J. P.; Fan, T. W.; Higashi, R. \& Somero, G. N. Extreme anoxia tolerance in embryos of the annual killifish Austrofundulus limnaeus: insights from a metabolomics analysis. $J$. Exp. Biol., 210(Pt. 13):2253-66, 2007.

Queiroz, G. R. G. Morfogénesis y plasticidad sináptica retiniana de larvas de lubina (Dicentrarchus labrax) adaptadas a la luz y a la oscuridad. Tesis Doctoral. Alicante, Departamento de Biotecnología, Universidad de Alicante, 2007.

Raymond, P. A.; Barthel, L. K. \& Curran, G. A. Developmental patterning of rod and cone photoreceptors in embryonic zebrafish. J. Comp. Neurol., 359(4):537-50, 1995.

Rojas, D. A.; Perez-Munizaga, D. A.; Centanin, L.; Antonelli, M.; Wappner, P.; Allende, M. L. \& Reyes, A. E. Cloning of hif-1alpha and hif-2alpha and mRNA expression pattern during development in zebrafish. Gene Expr. Patterns, 7(3):339-45, 2007.
Rojas, M.; Signore, I. A. \& Mejías, R. Morphogens during embryonic development of vertebrates. Int. J. Morphol., 32(1):319-26, 2014.

Rytkönen, K.; Vuori, K. A.; Primmer, C. R. \& Nikinmaa, M. Comparison of hypoxia-inducible factor-1 alpha in hypoxia-sensitive and hypoxiatolerant fish species. Comp. Biochem. Physiol. Part D Genomics Proteomics, 2(2):177-86, 2007.

Sánchez González, M. R. Caracterización in vivo e in vitro de progenitores neuronales en la retina de peces teleósteos. Tesis Doctoral. Salamanca, Departamento de Biología Celular y Patología, Universidad de Salamanca, 2009.

Semenza, G. L. HIF-1: mediator of physiological and pathophysiological responses to hypoxia. J. Appl. Physiol. (1985), 88(4):1474-80, 2000

Shang, E. H. \& Wu, R. S. Aquatic hypoxia is a teratogen and affects fish embryonic development. Environ. Sci. Technol., 38(18):4763-7, 2004

Stenkamp, D. L.; Hisatomi, O.; Barthel, L. K.; Tokunaga, F. \& Raymond, P. A. Temporal expression of rod and cone opsins in embryonic goldfish retina predicts the spatial organization of the cone mosaic. Invest. Ophthalmol. Vis. Sci., 37(2):363-76, 1996.

Stenkamp, D. L. \& Frey, R. A. Extraretinal and retinal hedgehog signaling sequentially regulate retinal differentiation in zebrafish. Dev. Biol., 258(2):349-63, 2003

Stenkamp, D. L. The rod photoreceptor lineage of teleost fish. Prog. Retin. Eye Res., 30(6):395-404, 2011

Vuori, K. A. M.; Soitamo, A.; Vuorinen, P. \& Nikinmaa, M. Baltic salmon (Salmo salar) yolk-sac fry mortality is associated with disturbances in the function of hypoxia-inducible transcription factor (HIF-12) and consecutive gene expression. Aquat. Toxicol., 68(4):301-13, 2004.

Wolpert, L. Principios del Desarrollo. $3^{\text {a }}$ ed. Madrid, Médica Panamericana, 2009.

\author{
Correspondence to: \\ Mario Pellón, MSc, PhD, Ophthalmologist \\ Associate Professor \\ Facultad de Medicina \\ Universidad de La Frontera \\ Casilla 54-D \\ Temuco \\ CHILE
}

Email: mario.pellon@ufrontera.cl

Received: 10-09-2015

Accepted: 14-12-2015 